\title{
NEW NORMAL : RESILIENSI AKADEMIK SISWA SEKOLAH MENENGAH PERTAMA
}

\author{
Diana Ariswanti Triningtyas ${ }^{1}$, Bagus Nugraha Adin Saputra ${ }^{2}$ \\ ${ }^{1-2}$ Universitas PGRI Madiun, Indonesia
}

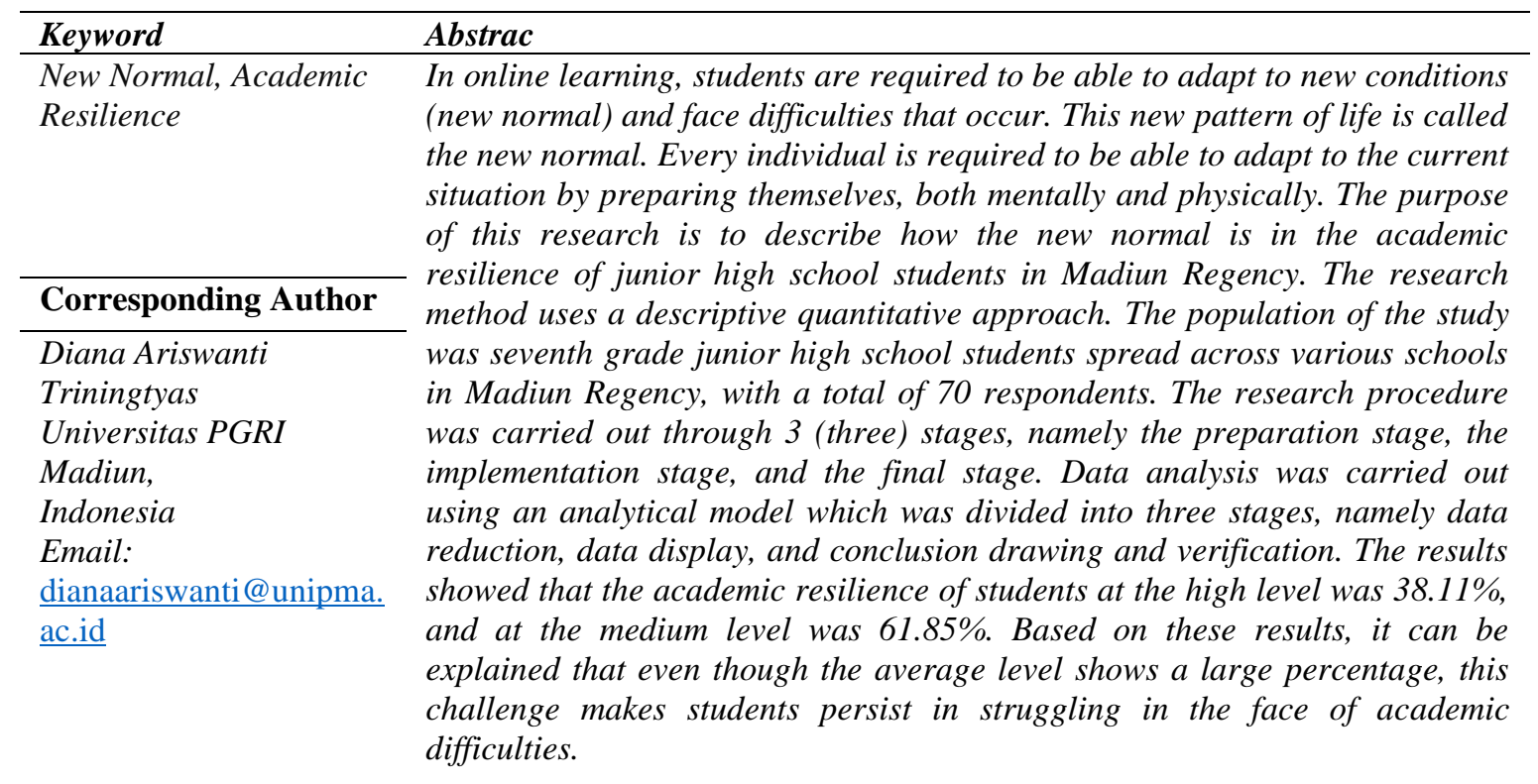

\begin{abstract}
Abstrak
Dalam pembelajaran daring, siswa dituntut untuk mampu beradaptasi dengan keadaan yang baru (new normal) serta menghadapi kesulitan yang terjadi. Pola kehidupan baru ini disebut dengan new normal. Setiap individu dituntut untuk bisa beradaptasi terhadap situasi yang terjadi saat ini dengan mempersiapkan diri, baik secara mental dan fisik. Tujuan dilakukan penelitian ini adalah untuk menggambarkan bagaimana new normal pada resiliensi akademik siswa Sekolah Menengah Pertama di Kabupaten Madiun. Metode penelitian menggunakan pendekatan kuantitaf deskriptif. Populasi penelitian yaitu siswa Sekolah Menengah Pertama kelas VII yang tersebar di berbagai sekolah di wilayah Kabupaten Madiun, dengan jumlah responden sebanyak 70 orang. Prosedur penelitian dilakukan melalui 3 (tiga) tahapan, yaitu tahap persiapan, tahap pelaksanaan, dan tahap akhir. Analisis data dilakukan dengan menggunakan model analisis yang terbagi menjadi tiga tahapan yakni reduksi data, display data, serta penarikan dan verifikasi kesimpulan. Hasil penelitian menunjukkan bahwa resiliensi akademik siswa pada tingkatan tinggi sebesar $38,11 \%$, dan pada tingkatan sedang sebesar 61,85\%. Berdasarkan hasil tersebut, dapatlah dijelaskan bahwa walaupun pada tingkatan sedang menunjukkan angka persentase yang besar, tantangan ini membuat siswa tetap gigih berjuang dalam menghadapi kesulitan akademik.
\end{abstract}

Kata Kunci: New Normal, Resiliensi Akademik 


\section{PENDAHULUAN}

Pandemi COVID-19 yang terjadi saat ini menimbulkan perubahan di berbagai sektor, salah satunya dalam dunia pendidikan. Kondisi ini membuat Pemerintah Republik Indonesia melalui Kementerian Pendidikan dan Kebudayaan mengeluarkan kebijakan Penyelenggaraan Belajar dari Rumah Dalam Masa Darurat Penyebaran COVID-19 yang tertuang dalam Surat Edaran nomor 15 tahun 2020. Hal ini bertujuan sebagai upaya mencegah penyebaran dan penularan COVID-19 di satuan pendidikan. Implementasi kebijakan baru tersebut mengubah sistem pembelajaran secara tatap muka menjadi pembelajaran daring (dalam jaringan/online). Pembelajaran daring merupakan aktivitas pembelajaran yang dilakukan dalam jarak jauh melalui media berupa internet (Bakia, dkk., 2012; Putria, dkk., 2020). Dalam pembelajaran daring, siswa dituntut untuk mampu beradaptasi dengan keadaan yang baru (new normal) serta menghadapi kesulitan yang terjadi. Pola kehidupan baru ini disebut dengan istilah new normal.

Menurut Wiku Adisasmita, selaku Ketua Tim Pakar Gugus Tugas Percepatan Penanganan COVID-19, istilah new normal diartikan sebagai terjadinya pola perubahan dalam melaksanakan kegiatan secara normal namun tetap memperhatikan protokol kesehatan untuk meminimalisir terjadinya penyebaran penularan virus COVID-19. Lebih lanjut, Wiku memaparkan bahwa prinsip new normal adalah dapat beradaptasi dengan pola hidup yang baru. Perubahan ini adalah untuk mengatur pola hidup yang baru, saat pandemi, yang kemudian akan dibawa terus ke depannya sampai ditemukannya vaksin untuk COVID-19. Pola kehidupan baru dalam dunia pendidikan ini menimbulkan pro dan kontra dikalangan orangtua, siswa, guru, serta sekolah/lembaga pendidikan. Setiap individu dituntut untuk bisa beradaptasi terhadap situasi yang terjadi saat ini dengan mempersiapkan diri, baik secara mental dan fisik. Kesulitan-kesulitan yang tidak dapat diatasi akan membahayakan keberlangsungan pendidikan siswa (Hart, 2012). Kapasitas individu untuk merespon setiap kesulitan akademik yang dihadapi disebut dengan resiliensi akademik.

Menurut Cassidy (2016), resiliensi akademik merupakan ketahanan atau kapasitas individu secara afektif, kognitif, dan perilaku untuk mengatasi kesulitan akademik yang dihadapinya dalam dunia pendidikan. Reivich \& Shatte (2002), mengungkapkan bahwa resiliensi akademik adalah kemampuan mengendalikan dalam hal dorongan serta keinginan, dan juga tekanan-tekanan yang muncul dari dalam diri individu berdasarkan pengalaman terhadap respon yang ada pada saat permasalahan muncul. Sedangkan Connor dan Davidson (2003), menyatakan bahwa resiliensi dapat juga dipandang sebagai pengukuran mengenai kemampuan coping stress yang dianggap sukses. Resiliensi ini menggambarkan bagaimana ketangguhan yang ada dalam diri seseorang.

Karakteristik individu yang memiliki tingkat resiliensi tinggi adalah mereka yang telah berhasil melakukan penyesuaian dan beradaptasi terhadap kesulitan yang sedang dihadapinya. Karakteristik individu yang resilien secara personal, mampu dan feksibel terhadap adanya perubahan, memiliki pengaturan emosi yang baik, memiliki daya tahan terhadap stress, memiliki kelekatan hubungan yang baik dengan orang lain, dan dapat mengatur dirinya sendiri (Reivich \& Shatte, 2002). Menurut Connor \& Davidson (2003), memaparkan dengan jelas karakter yang dimiliki individu yang resilien meliputi kompetensi personal serta standar yang tinggi dan kegigihan, stress sebagai sumber kekuatan, penerimaan yang positif, memiliki kendali diri dan juga pengaruh spiritual. 
Melalui karakteristik yang dimiliki, individu yang resilien adalah mereka yang mampu merespon dengan cepat terhadap kesulitan yang dihadapinya.

Dalam kondisi new normal, resiliensi akademik dapat membantu siswa beradaptasi dalam perubahan. Hal ini tampak dari hasil penelitian yang dilakukan oleh Kumalasari \& Akmal (2020), yang menyatakan bahwa individu yang memiliki resiliensi akademik yang baik dapat meningkatkan kesiapannya dalam belajar secara daring dan mencapai kepuasan. Hal yang sama juga diperoleh pada siswa di Korea, dimana tingkat kepuasan siswa terhadap pembelajaran berkorelasi positif dengan resiliensi akademik (Hwang \& Shin, 2018; Kim \& Lee, 2000; Noh, 2017). Sebuah penelitian yang melibatkan 6 (enam) orang mahasiswa program studi Doktor Psikologi Universitas Airlangga mengungkapkan bahwa seorang individu yang resilien akan mampu dengan cepat dalam menyesuaikan dirinya terhadap beragam hal negative yang dialaminya dan hal tersebut kemungkinan akan menghambatnya (Hendriani, 2017).

Berdasarkan latar belakang diatas, tampak bahwa new normal pada resiliensi akademik siswa sekolah menengah pertama (SMP) adalah hal yang penting untuk diteliti lebih lanjut. Tujuan dilakukan penelitian ini adalah untuk menggambarkan bagaimana new normal pada resiliensi akademik siswa Sekolah Menengah Pertama di Kabupaten Madiun.

\section{METODE}

Metode penelitian menggunakan pendekatan kuantitaf deskriptif. Penelitian deskriptif kuantitatif merupakan salah satu metode penelitian yang bertujuan mendeskripsikan secara sistematis, faktual serta akurat mengenai fakta fenomena tertentu. Adapun populasi yaitu siswa Sekolah Menengah Pertama kelas VII yang tersebar di berbagai sekolah di wilayah Kabupaten Madiun, dengan jumlah responden sebanyak 70 orang. Secara keseluruhan, tahapan dalam penelitian ini dilakukan secara daring (dalam jaringan/online) dan/atau luring, yang disesuaikan dengan situasi dan keadaan pada masa new normal. Prosedur penelitian dilakukan melalui 3 (tiga) tahapan, yaitu tahap persiapan, tahap pelaksanaan, dan tahap akhir. Pada prosedur tahap persiapan adalah mengurus surat ijin penelitian yang diterbitkan oleh Dekan Fakultas Keguruan dan Ilmu Pendidikan Universitas PGRI Madiun, untuk selanjutnya dilakukan perizinan kepada sekolah tujuan (sasaran), serta menyiapkan instrumen penelitian. Tahap pelaksanaan ini, dilakukan dengan membagikan kuesioner melalui aplikasi Google Form, dan melakukan analisis atas perolehan hasil yang telah diterima. Dalam tahap akhir, yakni menggambarkan serta mendeskripsikan hasil analisis dan membuat kesimpulan. Analisis data penelitian dilakukan dengan menggunakan model analisis Miles \& Huberman (1994), yang terbagi menjadi tiga tahapan yakni reduksi data, display data, serta penarikan dan verifikasi kesimpulan.

\section{HASIL}

Pengumpulan data diperoleh melalui kuesioner yang dibagikan melalui Google Form. Informasi yang diperoleh dari sejumlah responden yang tersebar di beberapa sekolah di wilayah Kabupaten Madiun, untuk selanjutnya dilakukan analisis agar dapat mendeskripsikan hasilnya secara sistematis. Tingkatan skala resiliensi akademik terbagi atas tinggi, sedang, dan rendah. Berikut dipaparkan hasil yang diperoleh, yaitu pada tingkatan tinggi sebesar $38,11 \%$ dan hasil resiliensi akademik pada tingkatan sedang 
sebesar $61,85 \%$. Dari hasil penelitian yang diperoleh menggambarkan bahwa pada tingkatan sedang menunjukkan angka persentase yang besar, tantangan ini membuat siswa tetap gigih berjuang dalam menghadapi tantangan akademik.

\section{PEMBAHASAN}

Hasil penelitian menunjukkan bahwa resiliensi akademik siswa pada tingkatan tinggi sebesar 38,11\%, dan pada tingkatan sedang sebesar 61,85\%. Berdasarkan hasil tersebut, dapatlah dijelaskan bahwa walaupun pada tingkatan sedang menunjukkan angka persentase yang besar, tantangan ini membuat siswa tetap gigih berjuang dalam menghadapi kesulitan akademik. Resiliensi akademik dalam masa new normal berperan penting bagi siswa Sekolah Menengah Pertama, terlebih dalam kondisi saat ini. Dampak wabah pandemi COVID-19 yang begitu cepat penyebarannya, menyebabkan banyaknya terjadi perubahan-perubahan baru dalam proses pembelajaran yang harus diikuti oleh siswa. Berdasarkan hasil yang diperoleh diketahui bahwa proses pembelajaran selama masa pandemi COVID-19 dijumpai beragam kesulitan, seperti siswa belum familiar dengan pembelajaran yang dilakukan secara daring karena keterbatasan setiap individu yang beragam, siswa mengalami kebingungan dalam menyelesaikan tugas-tugas yang diberikan, kecemasan saat mendapatkan nilai yang rendah, serta kendala akses internet dan kuota. Selama rentang perubahan yang terjadi, dibutuhkan kapasitas individu untuk selalu adaptif terhadap tuntutan-tuntutan baru dan mempersiapkan diri dalam menyelesaikan tantangan yang dihadapi. Sebagaimana yang diungkapkan oleh Hoge, dkk. (2007), bahwa resiliensi akan membantu individu untuk dapat kembali berfungsi secara normal saat dihadapkan pada situasi kritis.

Mengingat pentingnya resiliensi akademik bagi siswa khususnya kelas VII, yang berada dalam masa transisi, peralihan dari jenjang sekolah dasar ke jenjang menengah pertama, diharapkan individu atau siswa memiliki ketahanan dalam menyelesaikan tantangan-tantangan akademik yang dihadapinya. Kondisi siswa dalam hal ini adalah menerima perubahan yang terjadi dengan segala kesiapannya dan adaptif. Siswa yang memiliki resiliensi tinggi, dalam kondisi sesulit apapun akan tetap memiliki motivasi yang tinggi untuk mengatasi kesulitan akademik yang dihadapinya. Sebaliknya, resiliensi rendah adalah mereka yang menganggap bahwa kesulitan akademik yang dihadapinya dianggapnya sebagai beban dalam hidupnya. Beban tersebut akan dianggap sebagai suatu ancaman bagi dirinya sehingga siswa atau individu dapat mengalami frustasi atau ke-putusasaan dalam menyelesaikan tantangan-tantangan akademik yang dihadapinya. Resiliensi akademik siswa bukanlah bawaan melainkan dapat dilakukan melalui latihan saat menghadapi tekanan-tekanan tersebut. Hal ini merupakan modal utama yang diperlukan oleh individu atau siswa untuk selalu gigih dan berjuang dalam tekanan ataupun kesulitan yang dihadapi. Orang yang resilien adalah individu yang menunjukkan kapasitas untuk tetap baik, pulih, dan berkembang dalam menghadapi kesulitan dan kesengsaraan (Hardy, dkk.,2004; Poerwanto \& Prihastiwi, 2017).

\section{SIMPULAN}

Hasil penelitian menunjukkan bahwa resiliensi akademik siswa pada tingkatan tinggi sebesar 38,11\%, dan pada tingkatan sedang sebesar 61,85\%. Berdasarkan hasil tersebut, dapatlah dijelaskan bahwa walaupun pada tingkatan sedang menunjukkan angka 
persentase yang besar, tantangan ini membuat siswa tetap gigih berjuang dalam menghadapi kesulitan akademik. Resiliensi akademik dalam masa new normal berperan penting bagi siswa Sekolah Menengah Pertama, terlebih dalam kondisi saat ini. Selama rentang perubahan yang terjadi, dibutuhkan kapasitas individu untuk selalu adaptif terhadap tuntutan-tuntutan baru dan mempersiapkan diri dalam menyelesaikan tantangan yang dihadapi.

\section{DAFTAR PUSTAKA}

Bakia, M., Shear, L., Toyama, Y., \& Lassester, A. (2012). Understanding the Implications of Online Learning for Educational Productivity, Educational Technology, 1-75

Cassidy, S. (2016). The Academic Resilience Scale (ARS-30): A New Multidimensional Construct Measure. Frontiers in Psychology, 7 (Nov), 1-11

Connor, K.M., \& Davidson, J.R.T. (2003). Development of A New Resilience Scale : The Connor Davidson Resilience Scale (CD-RISC). Depression and Anxiety, 18: 7682

Hardy, S.E., Concato, J., Gill, T.M. (2004). Resilience of Community-Dwelling Older Persons. New York: Mc Graw Hill

Hart, C. (2012). Factors Associated With Student Persistence in an Online Program of Study: A review of the Literature. Journal of Interactive Online Learning, 11 (1), 1942

Hendriani, W. (2017). Adaptasi Positif Pada Resiliensi Akademik Mahasiswa Doktoral. Humanitas, Vol. 14, No. 2, Agustus 2020, h. 139-149

Hoge, E.A., Austin, A.E.D., \& Pollack, M.H. (2007). Resilience : Research evidence and conceptual considerations for posttraumatic stress disorder. Depression and Anxiety, 24(2), 139-152

Hwang, E., \& Shin, S. (2018). Characteristics of Nursing Students With High Levels of Academic Resilience : A Cross-Sectional Study. Nurse Education Today, 71 (March), 54-59

Kim, H., \& Lee, Y. (2020). The Influence of Optimism and Academic Resilience on The Major Satisfaction Among Undergraduate Nursing Students. Journal of the Korea Contents Association, 20 (1), 692-700

Kumalasari, D., Akmal, S.Z. (2020). Resiliensi Akademik dan Kepuasan Belajar Daring di Masa Pandemi COVID-19 : Peran Mediasi Kesiapan Belajar Daring. Persona : Jurnal Psikologi Indonesia, Vol. 9, No. 2, Desember 2020, h. 353-368

Miles, M.B., \& Huberman, M. (1994). Qualitative Data Analysis Second Edition. SAGE Publications

Noh, G.O. (2017). The Effects of Perfectionism and Academic Resilience on the Level of Students' Satisfaction with Nursing Major. The Journal of Korean Academic Society of Nursing Education, 23 (2), 205-213

Poerwanto, A., Prihastiwi, W.J. (2017). Analisis Prediktor Resiliensi Akademik Siswa Sekolah Menengah Pertama di Kota Surabaya. Psikosains, Vol. 12, No. 1, Februari 2017, 45-57

Putria, H., Maula, L.H., Uswatun, D.A. (2020). Analisis Proses Pembelajaran Dalam Jaringan (DARING) Masa Pandemi COVID-19 Pada Guru Sekolah Dasar. Jurnal Basicedu, Vol. 4, No. 4 tahun 2020, h. 861-872

Reivich, K. \& Shatte, A. (2002). The Resilience Factors. New York : Broadway Books 